\title{
Mineral status of soil, sea water, and mangrove (Avicennia marina) forages in several coastal areas of West Sumatra
}

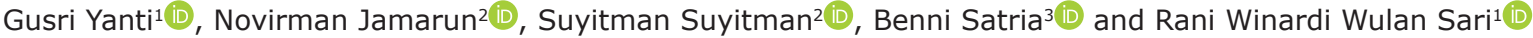

1. Department of Animal Science, Faculty of Animal Science, Andalas University, Kampus Limau Manis, Padang, West Sumatera, Indonesia; 2. Department of Animal Nutrition, Faculty of Animal Science, Andalas University, Kampus Limau Manis, Padang, West Sumatera, Indonesia; 3. Department of Agrotechnology, Faculty of Agriculture Andalas University, Kampus Limau Manis, Padang, West Sumatera, Indonesia.

Corresponding author: Novirman Jamarun, e-mail: novirman55@gmail.com

Co-authors: GY: gusriyanti594@gmail.com, SS: suyitman_psl@yahoo.co.id, BS: bennisatria@agr.unand.ac.id, RWWS: raniwinardi@gmail.com

Received: 12-01-2021, Accepted: 04-05-2021, Published online: 21-06-2021

doi: www.doi.org/10.14202/vetworld.2021.1594-1601 How to cite this article: Yanti G, Jamarun N, Suyitman S, Satria B, Sari RWW (2021) Mineral status of soil, sea water, and mangrove (Avicennia marina) forages in several coastal areas of West Sumatra, Veterinary World, 14(6): 1594-1601.

\begin{abstract}
Background and Aim: The availability of minerals in the soil affect the mineral content of mangrove leaves. This study aimed to determine the macro- and micromineral contents in the environment and mangrove leaves (Avicennia marina) as animal feed in the coastal areas of West Sumatra, Indonesia.

Materials and Methods: In this study, soil, water, and mangrove leaves were extracted from the mangrove plant's environment. The mineral contents were determined using the atomic absorption spectrophotometer of Beijing Rayleigh Analytical Instrument Corporation (make and country of origin). The total phenol and tannin contents were determined using the Folin-Ciocalteu and hide-powder methods, respectively.
\end{abstract}

Results: The mineral content of the soil affected the mineral content of the plants. The soil and leaves of $A$. marina in the Pariaman area were richer in terms of macro- and microminerals. The soil had $\mathrm{pH}$ value, organic carbon content, leaf nitrogen content, phosphorus, calcium, and potassium of $5.65,4.21 \%, 3.39 \%, 0.17 \%, 1.99 \%$, and $0.54 \%$, respectively. A. marina leaves had a total phenol and tannin contents of $24.51 \mathrm{mg} \mathrm{GAE} / \mathrm{g}$ check the unit and $4.09 \%$, respectively.

Conclusion: This research showed that the mineral content in the soil in several mangrove areas in West Sumatra has a positive correlation with the mineral content in the leaves of A. marina, which have a complete mineral content. Therefore, A. marina leaves could be recommended as a mineral source for ruminants.

Keywords: Avicennia marina, forage, mineral content, soil.

\section{Introduction}

The coastal area of West Sumatra, such as that in South Pesisir, is a productive location for the growth of ruminants. However, the lack of quality natural forage has led breeders to import feed ingredients from outside the region. This does not only reduce the efficiency of feed costs but also farmers in these locations are forced not to raise livestock owing to the challenge in finding forage and the limited quantity. Apart from the coastal area in Pesisir Selatan, the surrounding communities in the Padang Pariaman coast contain buffalo herds. Furthermore, the limited number of grasses acting as forages makes livestock development least attractive. The mangrove plants around the coastal area are considered to possess the potential to become forages. Furthermore, in Pakistan's Indus delta,

Copyright: Yanti, et al. Open Access. This article is distributed under the terms of the Creative Commons Attribution 4.0 International License (http://creativecommons.org/licenses/by/4.0/), which permits unrestricted use, distribution, and reproduction in any medium, provided you give appropriate credit to the original author(s) and the source, provide a link to the Creative Commons license, and indicate if changes were made. The Creative Commons Public Domain Dedication waiver (http://creativecommons.org/ publicdomain/zero/1.0/) applies to the data made available in this article, unless otherwise stated. approximately 16,000 camels and 11,000 cows eat mangrove leaves [1]. Each year, during the start of the flood season (June-July), camels from the remote areas of Sindh migrate to the mangrove area in herds and stay until October [2].

Based on this study, mangroves (Avicennia marina) have the potential to be a substitute for forage in ruminants. A. marina has this potential due to its high micro- and macromineral contents, which is required by livestock. However, the growth of a mangrove plant is largely determined by environmental conditions, such as water, soil, and climate, which support its growth [3]. These results yielded differences in micro- and macromineral contents.

The difference in micro- and macromineral contents in soil and water will significantly influence the same mineral in A. marina leaves. All leaves depend on soil and water for the supply of mineral nutrients, and ruminants derive most of their mineral nutrients from forage plants eaten. The concentration of mineral elements in forages depends on the interaction of several factors, such as soil, water, plant species, maturity level, yield, soil management, and climate [4]. Moreover, mineral deficiency in ruminants is directly related to soil and water characteristics [5]. 
This study aimed to determine the macro- and micromineral contents in the environment and mangrove leaves (Avicennia marina) as animal feed in the coastal areas of West Sumatra, Indonesia. The results will serve as a reference to map the potential of A. marina and determine the best place for A. marina leaves that contain macro- and microminerals needed to feed ruminants. Furthermore, it contributes to the fulfillment of the forages requirement of farmers around mangrove locations.

\section{Materials and Methods \\ Ethical approval}

This study does not need ethical approval as it is not related to animals.

\section{Studyperiod and location}

The study was conducted in August 2020. The area of mangrove forests in Indonesia ranges between 2.5 and 4.5 million hectares. West Sumatra Province has a coastal area of about 186,500 sq.km and a coastline length of $1973.24 \mathrm{~km}$ (Figure-1). The area of mangrove forests in West Sumatra is around 39,832 ha spread across the regencies of Mentawai 32,600 ha, Pasaman 6,273.5 ha, Pesisir selatan 325 ha, Agam 313.5 ha, Padang Pariaman 200 ha, and Padang 120 ha. Samples were processed at Water Laboratory of Technical Industry Department, Technic Faculty, Andalas University.

\section{Sample collection}

Soil, water, and mangrove (A. marina) leaf samples were obtained from several places in the coastal areas of West Sumatra, with three locations, including Regency of Padang, Pariaman, and Pesisir Selatan. These samples were collected at ten points in each area (soil, water, and A. marina leaves) and composited. Soil samples were obtained using a stainless steel sampling auger, with a depth of $15 \mathrm{~cm}$. In addition, a forage subsample was collected from each region by taking a few plots from each $A$. marina tree (such as taking on tea leaves). Soil and leaf samples were then dried in an oven at $60^{\circ} \mathrm{C}$ for $48 \mathrm{~h}$, milled using a mill, and filtered using a 1-mm stainless steel sieve for forage or a $2-\mathrm{mm}$ sieve for soil. The water sample that had been obtained was filtered using Whatman No 1 (GE Healthcare, China) and subsequently stored in a bottle and labeled.

\section{Mineral analysis}

A total of $1 \mathrm{~g}$ of soil and leaf samples were processed with sulfuric acid and hydrogen peroxide in a flask following the wet digestion method. Soil and forage samples were filtered and added with distilled water up to $50 \mathrm{~mL}$. The filtered sample was then stored in a bottle and labeled and placed in the laboratory. The mineral content in the soil, water, and forage samples was determined using the atomic absorption spectrophotometer method/tool of the Beijing Rayleigh Analytical Instrument Corporation after wet digestion. The digestion of wet process was performed by adding sulfuric acid to the sample and heating it on a dry block until the sample turned black. Hydrogen peroxide with $30 \%$ concentration was heated until the solution turned clear, diluted until $100 \mathrm{~mL}$, and filtered using Whatman No. 41 (GE Healthcare).

Nitrogen $(\mathrm{N})$, phosphorus $(\mathrm{P})$, and chlorine $(\mathrm{Cl})$ were measured using the Kjeldahl method, ultra violet (UV)-visible (Shimadzu) spectrophotometer with a wavelength of $889 \mathrm{~nm}$, and titration method, respectively; other minerals were measured using the atomic absorption spectrophotometer with a wavelength of potassium $(\mathrm{K}, 766.5 \mathrm{~nm})$, calcium $(\mathrm{Ca}, 422.7 \mathrm{~nm})$, magnesium (Mg, $285.2 \mathrm{~nm})$, sulfur $(\mathrm{S}, 666 \mathrm{~nm})$, iron $(\mathrm{Fe}, 248.3 \mathrm{~nm})$, copper $(\mathrm{Cu}, 324.7 \mathrm{~nm})$, manganese (Mn, $279.5 \mathrm{~nm})$, zinc $(\mathrm{Zn}, 213.9 \mathrm{~nm})$, molybdenum (Mo, $460 \mathrm{~nm})$, mercury $(\mathrm{Hg}, 253.7 \mathrm{~nm})$, and lead $(\mathrm{Pb}$, $283.3 \mathrm{~nm}$ ).

Analysis of the total phenol and tannin of mangrove leaves (A. Marina)

Total phenol (Folin-Ciocalteu method)

A total of $0.5 \mathrm{~g}$ powder sample was mixed with a $1-\mathrm{mL} 0.5 \%$ hexamethylenetetramine, $20-\mathrm{mL}$ acetone, and $2-\mathrm{mL} 25 \%$ hydrochloric acid $(\mathrm{HCl})$. The mixture was kept in a reflow refrigerator for 30 min and shaken with distilled water and ethyl acetate. The extract was separately used in the two solutions. In the first part, the extract was mixed with 1-mL aluminum chloride and 5\% (volume/volume) methanol-acetic acid for further measurement. Meanwhile, the second part was mixed with 5\% (volume/volume) methanol-acetic acid to produce a standard solution. After $30 \mathrm{~min}$ of incubation, the absorbance of both samples was measured at $425 \mathrm{~nm}$ (A). The total phenolic concentration was calculated using the formula: $(1.25 \times \mathrm{A}) \mathrm{m}$, where $\mathrm{m}=$ mass of sample in grams.

\section{Total tannin (hide-powder method)}

The mangrove (A. marina) leaves, which had been mashed to $0.5 \mathrm{~g}$, were mixed with $150 \mathrm{~mL}$ of distilled water and heated in a water bath for $30 \mathrm{~min}$ at $70^{\circ} \mathrm{C}$. The cooled extract was then quantitatively transferred into a $250-\mathrm{mL}$ volumetric flask, filtered, and used for the reaction. The results of the extraction were measured using the UV-visible (Shimadzu) spectrophotometer at a wavelength of $278.5 \mathrm{~nm}$ using pure tannins as standard.

\section{Statistical analysis}

The results were analyzed using generalized linear models method with IBM SPSS Statistics 26.0 version (IBM Corp., NY, USA).

\section{Results}

Soil $\mathrm{pH}$ values and organic carbon (C-org) content in the coastal areas of West Sumatra are shown in Table-1. The $\mathrm{C}$-org content and $\mathrm{pH}$ values were shown to be significantly different $(\mathrm{p}<0.05)$ and vary for each coastal area of West Sumatra. 
The macromineral content of soil, sea water, and A. marina leaves (Padang, Pariaman, and Pesisir Selatan) is shown in Tables-2-4. The macromineral contents of each region were shown to be significantly different $(\mathrm{p}<0.05)$.

The micromineral composition of soil, sea water, and $A$. marina leaves (Padang, Pariaman, and Pesisir Selatan) is shown in Tables-5-7. The micromineral contents of each region were shown to be significantly different $(\mathrm{p}<0.05)$. The composition of heavy metals $(\mathrm{Hg}$ and $\mathrm{Pb})$ in soil, sea water, and A. marina leaves (Padang, Pariaman, and Pesisir Selatan) is shown in

Table-1: C-organic content and $\mathrm{pH}$ value of soil in coastal areas of West Sumatra.

\begin{tabular}{lccc}
\hline $\begin{array}{l}\text { Variable } \\
\text { (\%) }\end{array}$ & \multicolumn{3}{c}{ Soil } \\
\cline { 2 - 4 } & Padang & Pariaman & Pesisir Selatan \\
\hline pH & $5.25^{\mathrm{a}} \pm 0.07$ & $5.65^{\mathrm{b}} \pm 0.06$ & $5.15^{\mathrm{a}} \pm 0.07$ \\
C-org & $3.54^{\mathrm{a}} \pm 0.13$ & $4.21^{\mathrm{b}} \pm 0.09$ & $3.60^{\mathrm{a}} \pm 0.11$ \\
\hline
\end{tabular}

a,b Superscript different means significantly different in a row $(p<0.05)$

Table-2: Macromineral content (percent dry) in growth areas (soil) in several coastal areas of West Sumatra.

\begin{tabular}{lccc}
\hline $\begin{array}{l}\text { Variable } \\
(\%)\end{array}$ & Padang & Pariaman & $\begin{array}{c}\text { Pesisir } \\
\text { Selatan }\end{array}$ \\
\hline $\mathrm{N}$ & $2.72^{\mathrm{a}} \pm 0.02$ & $3.00^{\mathrm{c}} \pm 0.014$ & $2.84^{\mathrm{b}} \pm 0.057$ \\
$\mathrm{P}$ & $0.32 \pm 0.04$ & $0.34 \pm 0.013$ & $0.29 \pm 0.007$ \\
$\mathrm{Ca}$ & $2.29^{\mathrm{b}} \pm 0.01$ & $2.43^{\mathrm{b}} \pm 0.014$ & $2.10^{\mathrm{ab}} \pm 0.014$ \\
$\mathrm{~K}$ & $0.41^{\mathrm{a}} \pm 0.106$ & $0.49^{\mathrm{b}} \pm 0.014$ & $0.41^{\mathrm{a}} \pm 0.014$ \\
$\mathrm{Mg}$ & $1.03^{\mathrm{b}} \pm 0.021$ & $0.90^{\mathrm{a}} \pm 0.021$ & $0.97^{\mathrm{a}} \pm 0.019$ \\
$\mathrm{~S}$ & $0.01 \pm 0.007$ & $0.02 \pm 0.007$ & $0.01 \pm 0.007$ \\
\hline
\end{tabular}

$a, b, c$ Different superscripts mean significant difference in a row $(p<0.05)$

Table-3: Macromineral content in growth areas (water) in several coastal areas of West Sumatra.

\begin{tabular}{lccc}
\hline $\begin{array}{l}\text { Variable } \\
(\%)\end{array}$ & Padang & Pariaman & $\begin{array}{c}\text { Pesisir } \\
\text { Selatan }\end{array}$ \\
\hline $\mathrm{N}$ & $9.82^{\mathrm{a}} \pm 0.028$ & $10.61^{\mathrm{b}} \pm 0.078$ & $11.84^{\mathrm{c}} \pm 0.163$ \\
$\mathrm{P}$ & $0.81^{\mathrm{a}} \pm 0.021$ & $0.77^{\mathrm{a}} \pm 0.021$ & $1.13^{\mathrm{b}} \pm 0.028$ \\
$\mathrm{~K}$ & $13.45^{\mathrm{a}} \pm 0.035$ & $14.45^{\mathrm{b}} \pm 0.269$ & $15.01^{\mathrm{b}} \pm 0.021$ \\
$\mathrm{Ca}$ & $4.13^{ \pm} \pm 0.036$ & $4.81 \pm 0.212$ & $4.47 \pm 0.092$ \\
$\mathrm{Mg}$ & $3.91^{\mathrm{a}} \pm 0.071$ & $4.23^{\mathrm{b}} \pm 0.049$ & $4.60^{\mathrm{c}} \pm 0.021$ \\
$\mathrm{~S}$ & $1.09^{\mathrm{a}} \pm 0.028$ & $1.32^{\mathrm{b}} \pm 0.048$ & $1.63^{\mathrm{c}} \pm 0.085$ \\
\hline
\end{tabular}

$a, b, c$ Different superscripts mean significant difference in a row $(p<0.05)$

Table-4: Macromineral content Avicennia marina leaves in several coastal areas of West Sumatra.

\begin{tabular}{lccc}
\hline $\begin{array}{l}\text { Variable } \\
(\%)\end{array}$ & Padang & Pariaman & $\begin{array}{c}\text { Pesisir } \\
\text { Selatan }\end{array}$ \\
\hline $\mathrm{N}$ & $3.08^{\mathrm{a}} \pm 0.106$ & $3.49^{\mathrm{b}} \pm 0.078$ & $3.05^{\mathrm{a}} \pm 0.049$ \\
$\mathrm{P}$ & $0.14 \pm 0.028$ & $0.17 \pm 0.021$ & $0.17 \pm 0.028$ \\
$\mathrm{~K}$ & $1.83^{\mathrm{a}} \pm 0.026$ & $1.99^{\mathrm{b}} \pm 0.035$ & $2.04^{\mathrm{c}} \pm 0.014$ \\
$\mathrm{Ca}$ & $0.38^{\mathrm{a}} \pm 0.064$ & $0.54^{\mathrm{b}} \pm 0.028$ & $0.69^{\mathrm{c}} \pm 0.028$ \\
$\mathrm{Mg}$ & $0.87^{\mathrm{b}} \pm 0.049$ & $0.15^{\mathrm{a}} \pm 0.014$ & $0.81^{\mathrm{b}} \pm 0.021$ \\
$\mathrm{~S}$ & $0.005 \pm 0.001$ & $0.009 \pm 0.001$ & $0.007 \pm 0.001$ \\
\hline $\mathrm{a}, \mathrm{b}, \mathrm{c}$ Different superscripts mean significant difference in a \\
row (p<0.05)
\end{tabular}

Table- 8 . The content of heavy metals $(\mathrm{Hg}$ and $\mathrm{Pb})$ in the soil was shown to be significantly different $(\mathrm{p}<0.05)$, whereas that in the water and A. marina leaves were not significantly different.

\section{Discussion}

Macromineral content of soil, water, and leaves of A. marina

The $\mathrm{pH}$ and C-org content of the soil where A. marina grows is shown in Table- 1 . The soil $\mathrm{pH}$ is 5.15-5.65, which is acidic because it originates from swampy areas affected by tidal water. The mangrove soil is muddy and rich in alluvial deposits, clay, humus, nonorganic salt content, $\mathrm{Ca}, \mathrm{S}, \mathrm{Fe}$, and $\mathrm{Mn}$, which influence its aroma and dark color. According

Table-5: Micromineral content in soil in several coastal areas of West Sumatra.

\begin{tabular}{lccc}
\hline $\begin{array}{l}\text { Micro } \\
\text { minerals } \\
(\mathbf{p p m})\end{array}$ & Padang & Pariaman & $\begin{array}{c}\text { Pesisir } \\
\text { Selatan }\end{array}$ \\
\hline $\mathrm{Fe}$ & $6.53^{\mathrm{a}} \pm 0.064$ & $8.06^{\mathrm{b}} \pm 0.078$ & $8.89^{\mathrm{c}} \pm 0.127$ \\
$\mathrm{Cu}$ & $4.18^{\mathrm{a}} \pm 0.035$ & $8.86^{\mathrm{b}} \pm 0.076$ & $13.38^{\mathrm{c}} \pm 0.035$ \\
$\mathrm{Mn}$ & $15.85^{\mathrm{a}} \pm 0.064$ & $28.03^{\mathrm{c}} \pm 0.035$ & $20.92^{\mathrm{b}} \pm 0.198$ \\
$\mathrm{Zn}$ & $13.89^{\mathrm{a}} \pm 0.021$ & $14.43^{\mathrm{a}} \pm 0.064$ & $20.20^{\mathrm{b}} \pm 0.014$ \\
$\mathrm{Mo}$ & $3.40^{\mathrm{c}} \pm 0.035$ & $2.06^{\mathrm{a}} \pm 0.042$ & $2.39^{\mathrm{b}} \pm 0.134$ \\
$\mathrm{Cl}$ & $1.01^{\mathrm{b}} \pm 0.028$ & $0.90^{\mathrm{a}} \pm 0.028$ & $0.81^{\mathrm{a}} \pm 0.035$ \\
\hline $\mathrm{a}$,b,cDifferent superscripts mean significant difference in a \\
row $(\mathrm{p}<0.05)$
\end{tabular}

Table-6: Micromineral content sea water in several coastal areas of West Sumatra.

\begin{tabular}{|c|c|c|c|}
\hline $\begin{array}{l}\text { Micro } \\
\text { minerals } \\
(\mathrm{ppm})\end{array}$ & Padang & Pariaman & $\begin{array}{l}\text { Pesisir } \\
\text { Selatan }\end{array}$ \\
\hline $\mathrm{Fe}$ & $0.33 \pm 0.049$ & $\begin{array}{l}0.30 \pm \\
0.035\end{array}$ & $0.34 \pm 0.028$ \\
\hline $\mathrm{Cu}$ & $0.04^{a} \pm 0.006$ & $\begin{array}{c}0.07^{b} \pm \\
0.006\end{array}$ & $0.08^{a} \pm 0.007$ \\
\hline $\mathrm{Mn}$ & $0.05^{\mathrm{a}} \pm 0.002$ & $\begin{array}{l}0.1^{\mathrm{ab} \pm} \\
0.003\end{array}$ & $0.14^{c} \pm 0.016$ \\
\hline Zn & $0.086 \pm 0.005$ & $\begin{array}{c}0.115 \pm \\
0.074\end{array}$ & $0.149 \pm 0.021$ \\
\hline Mo & $0.081 \pm 0.004$ & $\begin{array}{c}0.090 \pm \\
0.005\end{array}$ & $0.111 \pm 0.069$ \\
\hline $\mathrm{Cl}$ & $135.88^{a} \pm 0.120$ & $\begin{array}{c}154.11^{\mathrm{b}} \pm \\
0.032\end{array}$ & $239.50^{c} \pm 0.064$ \\
\hline
\end{tabular}

Table-7: Micromineral content in Avicennia marina leaves in several coastal areas of West Sumatra.

\begin{tabular}{lccc}
\hline $\begin{array}{l}\text { Micro } \\
\text { minerals } \\
(\mathbf{p p m})\end{array}$ & Padang & Pariaman & $\begin{array}{c}\text { Pesisir } \\
\text { Selatan }\end{array}$ \\
\hline $\mathrm{Fe}$ & $1.00^{\mathrm{a}} \pm 0.021$ & $1.18^{\mathrm{b}} \pm 0.028$ & $1.19^{\mathrm{b}} \pm 0.014$ \\
$\mathrm{Cu}$ & $0.49 \pm 0.127$ & $0.67 \pm 0.064$ & $0.89 \pm 0.007$ \\
$\mathrm{Mn}$ & $1.05^{\mathrm{a}} \pm 0.035$ & $1.23^{\mathrm{b}} \pm 0.049$ & $1.65^{\mathrm{c}} \pm 0.035$ \\
$\mathrm{Zn}$ & $2.02^{\mathrm{a}} \pm 0.021$ & $2.27^{\mathrm{b}} \pm 0.035$ & $2.52^{\mathrm{c}} \pm 0.057$ \\
$\mathrm{Mo}$ & $0.41 \pm 0.028$ & $0.43 \pm 0.021$ & $0.47 \pm 0.028$ \\
$\mathrm{Cl}$ & $0.75 \pm 0.035$ & $0.71 \pm 0.085$ & $0.57 \pm 0.057$ \\
\hline $\mathrm{a}, \mathrm{b}, \mathrm{c}$ Different superscripts mean significant difference in a \\
row $(p<0.05)$
\end{tabular}

Veterinary World, EISSN: 2231-0916 


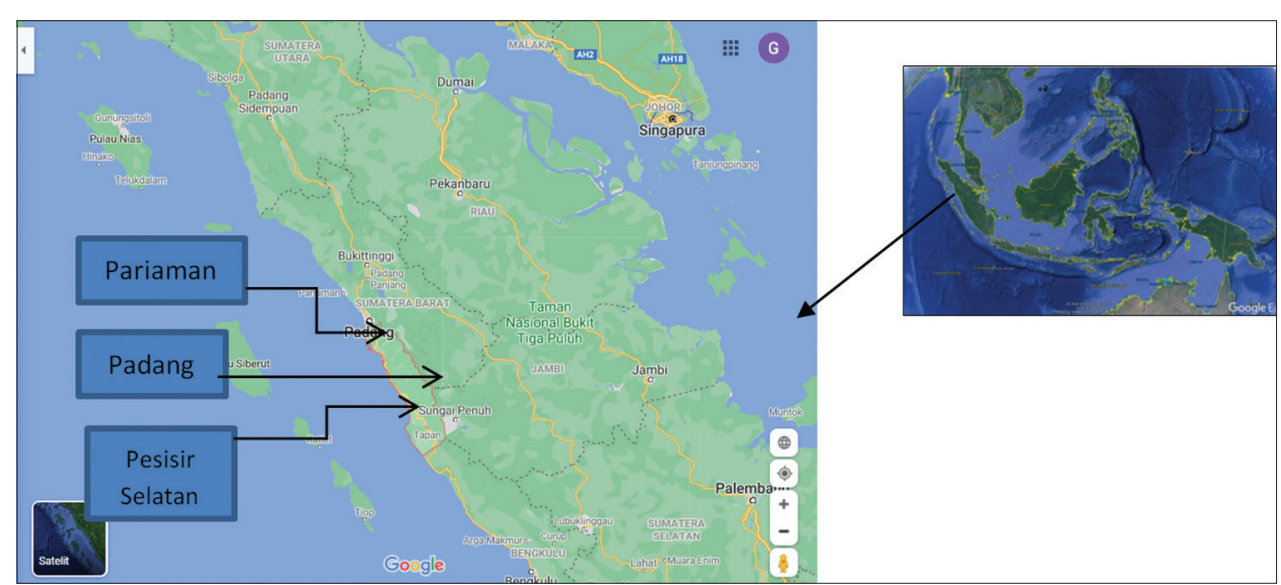

Figure-1: Map of research location in West Sumatera Province, Indonesia [Source: www.maps.google.com].

Table-8: Heavy metal content in soil, sea water and Avicennia marina leaves in several coastal areas of West Sumatra.

\begin{tabular}{lccc}
\hline $\begin{array}{l}\text { Variable } \\
(\mathbf{p p m})\end{array}$ & Padang & Pariaman & $\begin{array}{c}\text { Pesisir } \\
\text { Selatan }\end{array}$ \\
\hline $\begin{array}{c}\text { Soil } \\
\mathrm{Hg}\end{array}$ & $0.42^{\mathrm{a}} \pm 0.021$ & $0.57^{\mathrm{b}} \pm 0.021$ & $0.67^{\mathrm{c}} \pm 0.007$ \\
$\mathrm{~Pb}$ & $0.98 \pm 0.062$ & $1.22 \pm 0.049$ & $0.93 \pm 0.035$ \\
$\mathrm{Water}$ & & & \\
$\mathrm{Hg}$ & $0.0036 \pm 0.001$ & $0.0040 \pm 0.005$ & $0.0028 \pm 0.012$ \\
$\mathrm{~Pb}$ & $0.0083 \pm 0.002$ & $0.0094 \pm 0.007$ & $0.0089 \pm 0.028$ \\
Avicennia marina leaves & & \\
$\mathrm{Hg}$ & $0.08 \pm 0.021$ & $0.04 \pm 0.003$ & $0.07 \pm 0.021$ \\
$\mathrm{~Pb}$ & $0.23 \pm 0.007$ & $0.24 \pm 0.005$ & $0.25 \pm 0.171$ \\
\hline
\end{tabular}

$\mathrm{a}, \mathrm{b}, \mathrm{c}$ Different superscripts mean significant difference in a row $(p<0.05)$

Table-9: Polyphenol and Tannin content of Avicennia marina leaves grow in several coastal areas of West Sumatra.

\begin{tabular}{lccc}
\hline Variable & Padang & Pariaman & $\begin{array}{c}\text { Pesisir } \\
\text { Selatan }\end{array}$ \\
\hline $\begin{array}{l}\text { Polyphenol } \\
\text { (mg GAE/g) }\end{array}$ & $13.02^{\mathrm{a}} \pm 0.046$ & $24.51^{\mathrm{b}} \pm 0.056$ & $10.03^{\mathrm{a}} \pm 0.037$ \\
Tannin (\%) & $4.24 \pm 0.034$ & $4.092^{\mathrm{b}} \pm 0.012$ & $1.40^{\mathrm{a}} \pm 0.018$ \\
\hline
\end{tabular}

a,b Different superscripts mean significant difference in a row $(p<0.05)$

Table-10: Correlation Between macromineral, micromineral, and heavy metals in soil to leaves.

\begin{tabular}{lccc}
\hline & \multicolumn{3}{c}{ Leaves } \\
\cline { 2 - 4 } & Macrominerals & Micromineral & Heavy metals \\
\hline Soil & $0.969 * *$ & $0.694 * *$ & $0.787 *$ \\
\hline
\end{tabular}

*Correlation significant at the $0.05, * *$ Correlation is significant at the 0.01

to Heriyanto and Suharti [6], the acidity $(\mathrm{pH})$ of this soil is approximately 5 . The soil $\mathrm{pH}$ is strongly influenced by the C-org content. The highest C-org content $(4.21 \%)$ was found in the Pariaman soil. Based on physical observations, this soil is darker and contains several organic matter derived from mangrove litter and the weathering of dead roots. The organic matter is another factor that greatly affects soil $\mathrm{pH}$ conditions.
During decomposition, the organic matter produces organic acids that reduce the $\mathrm{pH}$ of the soil and its environment, including the surrounding water[7].

According to Gordon [8], the mangrove area is defined as a dynamic place where mud and land are continuously formed by plants that slowly turn into semi-terrestrial areas (semi-land). Soil (sediment) that is formed serves as a place for living organisms to thrive and find food. The fertility of mangrove sediments is due to the organic material they contain. The organic material is one of the components of the waterbased substrate, which consists of heaps of plant and animal remains. Furthermore, mangrove ecosystems are tropical and subtropical coastal vegetation communities dominated by several species of mangrove trees that grow and develop in tidal muddy coastal areas [9]. These vegetation formers are tree species that adapt physiologically to relatively high salinity, delicate soil structure, composition, and influence from tides.

In the Pariaman area, the soil $\mathrm{N}$ content ranged from $2.7 \%$ to $3 \%$, which is significantly different from the Padang and South Pesisir mangrove areas. The increase in the total soil $\mathrm{N}$ content corresponds with the $\mathrm{C}$-org content in the soil. It occurs due to the decomposition of organic matter, where $\mathrm{N}$ is the main element derived. The decomposition process is largely dependent on the quality and amount of organic material. According to Hugues et al. [10], one of the factors influencing the rate of decomposition is an increase in the soil $\mathrm{pH}$. A decrease toward the neutral will increase the activity of soil microorganisms. Since the activity of microorganisms increases in the soil, the $\mathrm{C} / \mathrm{N}$ ratio is also decreased; therefore, $\mathrm{N}$ is available to plants.

The factors of soil and plants that affect forage mineral content have been widely reported[11]. In plants, the mineral content is strongly influenced by the quantity and availability of minerals in the soil. Availability is very significant because, from several minerals, only a small portion can be absorbed. Furthermore, the process of soil mineral decomposition is influenced by the origin of the source rock, 
surface erosion, application of fertilizers, and waste materials. Their availability in the soil and uptake by plants depends on factors, such as $\mathrm{pH}$, moisture, and drainage conditions.

$\mathrm{N}$ is the main food for plants as it is a constituent of protein and chlorophyll, which activates the photosynthesis process. $\mathrm{N}$ has the most significant role in various physiological processes, such as giving dark green color to plants, increasing the number of leaves, stems, and others. In addition, it influences rapid growth and increases the protein content of plants. This function greatly determines the quality of the A. marina leaves as a forage. When the data content of $\mathrm{N}(3 \%)$ is converted into crude protein, the crude protein content in A. marina leaves in the coastal area of West Sumatra is approximately $20 \%$. This content is high enough to meet the protein requirement of ruminants. According to Ghosh et al. [12], the crude protein content $A$. marina leaves is estimated to be $15 \%$, and this also encourages the absorption and utilization of other nutrients, including $\mathrm{P}$ and $\mathrm{Ca}$, for overall plant growth.

The dissolved $\mathrm{P}$ content is an indicator that determines the fertility level of the water. In this research location, the sea water was classified in the normal category due to the P level of $0.7-1.1 \%$. This was also influenced by the condition of mangrove stands in the location. P typically appears in low concentrations in natural sea water due to a large amount of mobility, although the total phosphate concentration often ranges between $0.01 \mathrm{mg} / \mathrm{L}$ and $>200 \mathrm{mg} / \mathrm{L}[13]$.

$\mathrm{P}$ in soil, sea water, and mangrove plants vary in amounts, although not statistically significant. The $\mathrm{P}$ content in the soil is approximately $0.3 \%, 0.7$ $1.1 \%$ in sea water, and $0.1 \%$ in $A$. marina leaves. $\mathrm{P}$ is essential for plant growth and is found in every living plant cell. It is involved in photosynthesis, respiration, energy storage and transfer, cell division, and enlargement. The results showed that $\mathrm{P}$ is an important component of the photosynthetic process, systematically involved in the formation of sugars, oils, and starches that further aids in the conversion of solar to chemical energy, proper maturation of plants, and the ability to withstand stress. Moreover, ruminants require a large amount of $\mathrm{P}$ elements. The adequacy of $\mathrm{P}$ in ruminants is obtained from forage containing it. In addition, $\mathrm{P}$ plays a significant role in the development and metabolism of microorganisms in the rumen[14]. Its deficiency results in reproductive disorders, such as anesthesia, low conception, long calving intervals, embryo death, and delayed sexual maturity[15].

The $\mathrm{Ca}$ content in mangrove leaves ranged between $1 \%$ and $2 \%$. The forage originating from South Pesisir regency contains the highest $\mathrm{Ca}$ content of $2.04 \%$. This content is able to meet the Ca requirement of ruminants. Approximately $99 \%$ of the total $\mathrm{Ca}$ in the body functions as a structural component of bones and teeth. The remaining $1 \%$ is involved in vital functions, such as blood clotting, membrane permeability, neuromuscular stimulation, secretion of certain hormones, and activation of enzymes. The lack of $\mathrm{Ca}$ results in soft and weak bones and decreases growth and milk production [5]. Ca and $\mathrm{P}$ have a very close relationship with each other in terms of metabolic processes in animals. Furthermore, the balanced nutritional value of $\mathrm{Ca}$ and $\mathrm{P}$ depends on the adequacy of the supply of each feed source, the ratio, and the presence of Vitamin D. The ideal Ca and P ratio is between $2: 1$ and $1: 1[12]$.

The $\mathrm{Mg}$ content in mangrove leaves (A. marina) ranged between $0.1 \%$ and $0.9 \%$. This content is high and adequately meets the requirement of ruminants. The function of $\mathrm{Mg}$, in general, includes cofactors of $>300$ enzymes that function in carbohydrate, fat, and protein metabolism[16], form ribosomes, and maintain membrane integrity through bonding with phospholipids [17]. Furthermore, it is required in membrane energy transport, cyclic adenosine monophosphate formation and transmission of genetic material, muscle contraction, nerve transmission, and constitutes the main components of bone structure[18]. The normal $\mathrm{Mg}$ percentage in the body is $65-70 \%, 15 \%, 15 \%$, and $1 \%$ in bones, muscles, soft tissues, and extracellular fluid, respectively [19].

The $\mathrm{K}$ content in mangrove leaves ranged between $0.3 \%$ and $0.7 \%$. This value considerably varies and is highest in South Pesisir. For forage, in general, $\mathrm{K}$ and $\mathrm{Cl}$ have a similar function. $\mathrm{K}$ maintains the osmotic pressure, controls water balance, and regulates acid-base balance. Furthermore, it functions in muscle contraction and nerve impulse transmission, whereas $\mathrm{Cl}$ is required for the formation of $\mathrm{HCl}$ in the stomach. The signs of $\mathrm{Cl}$ and $\mathrm{K}$ deficiency are nonspecific and reduce feed intake, growth, and milk production [4]. Muscle weakness, including the uterine muscles, occurs due to $\mathrm{K}$ deficiency, which indirectly causes reproductive problems by inhibiting the use of protein and energy. This results in weakness of the uterine muscles, thereby increasing the risk of metritis and placental retention[20]. Furthermore, the provision of excessive amounts of $\mathrm{K}(5 \%$ dry matter) is believed to cause delayed puberty and ovulation, impaired corpus luteum development (yellow body), and an increased incidence of anestrus in cattle[21].

The macromineral content in the coast of West Sumatra was relatively varied and sufficient to meet the mineral needs of ruminants. According to Maxwell and Lai[22], A. marina is used as a candidate for mineral nutrition supplementation to increase milk production in dairy cows in New Zealand. According to Sathe et al. [23], this is due to the high nutritional content and suitability for replacing grass or plant sources that are frequently used as animal feed. However, the content of $\mathrm{P}$ and $\mathrm{Ca}$ in $A$. marina has a significant comparison with some feed substances, such as Oryza sativa or Arachis hypogea. 
Micromineral content of soil, water, and mangrove leaves

The results of the micromineral content analysis in sea water, soil, and mangrove leaves are shown in Table- 3 . The value of Fe contained in the soil around mangrove plants is relatively high. The Fe content in each region was shown to be significantly different, with the highest content found in South Pesisir at $8.89 \mathrm{ppm}$. Furthermore, the high $\mathrm{Fe}^{2+}$ values can be explained by the anaerobic conditions of mangrove soils, which favor greater dissolution in this environment. This condition is equally supportive in increasing the amount of $\mathrm{Mn}^{2+}$ and related to the amount of organic matter in the soil. Conversely, $\mathrm{Zn}^{2+}$ is expressed in high-enough concentrations, as a negative response to aerobic conditions during tidal and soil drying processes. Moreover, it is associated with carbon dioxide accumulation from the decomposition of organic matter and $\mathrm{pH}$ fluctuations, which according to Numbere and Camilo[24], allows the precipitation of zinc carbonate, zinc hydroxide, and zinc sulfide to occur.

In general, the micromineral requirements of livestock are relatively varied. These levels will affect the quality of mangrove leaves (A. marina) as forage. The $\mathrm{Zn}$ content in forage was observed to range from 2.00 to $2.52 \mathrm{mg} / \mathrm{g}$, whereas the $\mathrm{Zn}$ requirement for ruminants is $10-50 \mathrm{mg} / \mathrm{kg}$. When there is a $\mathrm{Zn}$ deficiency status, the rumen microbial activity is not optimal. Therefore, the level of feed utilization will be lower, which in turn, will reduce livestock productivity [5]. Zn deficiency in ruminants, results in the loss of weight, appetite, and hair, with skin lesions on the legs, neck, head, and around the nose, excessive salivation, and reproductive problems. Zn deficiency in males leads to a decreased testicular development and sperm production, whereas in females, it causes cyclical disorders and conception rates [25].

$\mathrm{Zn}$ is an essential micromineral for growth, reproduction, immune system, gene expression, enzyme processes, performance, and health of livestock [17]. Furthermore, it functions in livestock metabolism and involves the regeneration of keratin and epithelial tissue integrity, bone metabolism, nucleic acid synthesis, cell division, protein synthesis, catalytic ions, structure and regulation of enzymes and transcription factors, participating in carbohydrate, fat, and protein metabolism, sexual development and spermatogenesis, immune function, and appetite control through its action on the central nervous system. Zn also participates in the structural, catalytic, and regulatory functions of most species [26].

The $\mathrm{Cu}$ levels in $A$. marina mangrove leaves were not significantly different in each region, as it ranged between 0.4 and $0.8 \mathrm{ppm}$, whereas the $\mathrm{Cu}$ requirements for ruminant is $15-20 \mathrm{mg} / \mathrm{kg}$. $\mathrm{Cu}$ is an essential micronutrient in all living organisms, from plants to mammals, and is needed in very small amounts. This element plays a significant role in various physiological functions of the hematological, nervous, cardiovascular, reproductive, and immune systems [27]. Furthermore, it is a vital microelement in the pigmentation of mammalian skin and hair. Tyrosinase, a Cu-containing enzyme (the enzyme required for the conversion of tyrosine to melanin) is very important for the pathway of pigmentation. Therefore, decreased tyrosinase concentrations and depigmentation in ruminants are observed as early signs of hypocuprosis or $\mathrm{Cu}$ deficiency [28].

The Mn content ranged between 1.2 and $1.6 \mathrm{ppm}$ in A. marina leaves. The Mn requirement for ruminants is $0.20-0.60 \mathrm{mg} / \mathrm{kg}$. Mn from leaves originating from the South Coast is relatively high at $1.6 \mathrm{ppm}$. This content is sufficient to meet the Mn requirement of ruminants. According to Mousavi et al. [29] stated that Mn mineral deficiency rarely occurs because the Mn content in feed is sufficient for livestock needs. Mn minerals are needed in small amounts, although have a very significant function. According to Hansen et al. [30], its deficiency in livestock will result in dwarfism.

The Mo content of $A$. marina leaves in each region was not significantly different at $0.4 \mathrm{ppm}$, since the normative Mo requirement in ruminants is $<100 \mu \mathrm{g} / \mathrm{kg}^{1}$. A high amount of Mo suppresses $\mathrm{Cu}$ availability and causes physiological $\mathrm{Cu}$ deficiency in ruminants. Total $\mathrm{S}$ or sulfate in the ration generally supplements the Mo effect. The $\mathrm{Cu}$ to Mo ratio in feed is important regardless of the absolute number of each. Therefore, in consideration of the significance of dietary S content, it is not possible to establish food safe limits for $\mathrm{Cu}$ and Mo. Physiological $\mathrm{Cu}$ deficiency occurs due to the following four types of feed combinations: (1) High Mo, generally above 100 ppm; (2) low $\mathrm{Cu}$ to Mo ratio, 2:1 or less; (3) $\mathrm{Cu}$ deficiency, below 5 ppm; and (4) high protein, 20-30\% protein in fresh forage. The latter situation may be due to the high levels of sulfides produced from sulfuric amino acids during rumen fermentation.

The $\mathrm{Cl}$ content in plants is sufficient to meet the requirements of ruminants, since it ranged between 0.5 and $0.7 \mathrm{ppm}$ in leaves. Furthermore, the content in each region is not significantly different. Chloride is the main anion in the extracellular fluid, 80-85\% are inorganic and $15-20 \%$ are organic[31]. Chloride plays a significant role in the production of $\mathrm{HCl}$ in the abomasum and acid-base balance of the body [32]. It also plays a role in the absorption of amino acids and minerals, digestive proteins, and the regulation of osmotic pressure in the acid-base balance [4].

\section{Heavy metal content in soil, sea water, and man- grove plants}

A. marina grows in extreme environments, where water and land experience ebbs and flows carrying various types of minerals. It is undeniable that plants will absorb non-essential minerals or even become toxic. From the analysis that has been performed, A. marina leaves in the coastal area of 
West Sumatra contain $\mathrm{Hg}$ at $0.04-0.08 \mathrm{ppm}$ and $\mathrm{Pb}$ at $0.2 \mathrm{ppm}$. Meanwhile, heavy metal content in the leaves of each region was not significantly different. The content of $\mathrm{Hg}$ and $\mathrm{Pb}$ is relatively high in the soil, although it does not correlate with their solubility in water and absorption by A. marina plants. According to Kennady et al. [33], the heavy metal content in the soil is $<7$ and $<200 \mathrm{ppm}$ for $\mathrm{Hg}$ and $\mathrm{Pb}$, respectively. Therefore, no heavy metal content in the study location exceeds the threshold. The mangrove leaves had a lower heavy metal content than the soil. This is because mangrove trees only require a small amount of these elements for growth [34].

$\mathrm{Pb}$ and $\mathrm{Hg}$ are toxic metals that have negative effects on livestock, even when consumed in small amounts. These metals inhibit the growth, productivity, and reproducibility of livestock and even cause death. Cows and sheep, which consume grass containing $\mathrm{Pb}$ at $5 \mathrm{mg} / \mathrm{kg}$ dry weight of grass/day, did not show any symptoms. However, pregnant ewes, which consumed grass containing $\mathrm{Pb} 30 \mathrm{mg} / \mathrm{kg}$ dry weight of grass/day for a long period of time, showed symptoms of poisoning, especially in conditions of starvation [33].

\section{Total phenol and tannin contents}

The total phenol and tannin contents of A. marina leaves in the three sampling locations had shown a significant difference (Table-9). The number of polyphenols Avicennia in the Pariaman area was the highest compared with plants in other locations, reaching $24.51 \mathrm{mg}$ GAE. Meanwhile, in the Padang and South Pesisir areas, plants share the same tendency and potential. Polyphenols are secondary metabolite compounds produced by plants to protect them from external disturbances. The high amounts of polyphenols observed in the Pariaman area were due to the growth of A. marina in the area, which often occurs due to storms and human touch.

The content of secondary metabolites in plants is influenced by the environment, such as altitude, rainfall, and temperature. The influence of environmental factors interacts with genetic factors in the expression of secondary metabolites. Therefore, the production and excretion of secondary metabolites are influenced by temperature, light, soil, microorganisms, and nutritional status. Furthermore, secondary metabolite contents vary, depending on time and location. It is also related to variations in climatic and soil conditions, such as air, soil temperature, and soil moisture.

The tannin content of $A$. marina leaf samples extracted in the Padang and Pariaman areas was not significantly different at $4.24 \%$ and $4.092 \%$, respectively; meanwhile, in the South Pesisir area, the tannin content was lower at $1.40 \%$. The tannin content of $A$. marina leaves was still within tolerance limits for ruminants. Furthermore, tannins present in certain amounts will provide a positive value in increasing the digestibility of feed. Tannins are secondary metabolites synthesized and found in plants. They are classified as polyphenolic compounds with the ability to form complex compounds with other macromolecules. They also interact with proteins derived from feed, thereby reducing their availability for rumen microorganisms [35]. Therefore, this condition positively influences increasing forage digestibility, since proteins will be protected by tannins from the degradation of rumen microorganisms. These metabolites are mainly found in the post-rumen gastrointestinal tract. The tannin-protein binding complex can then be released at low $\mathrm{pH}$ in the abomasum, which enables protein degradation by the enzyme, pepsin. Therefore, the amino acids it contains are readily available to livestock. This explains the use of tannins for manipulating the level of protein degradation in rumens correlation between macromineral, micromineral, and heavy metals in soil to leaves showed at the Table-10. The mineral content of the soil has a positive correlation with the mineral content of the leaves. The higher the mineral content in the soil, the higher the mineral content in the leaves (Table-10).

\section{Conclusion}

This study showed that the minerals content of the soil in several mangrove areas of West Sumatra have a positive correlation with the minerals composition of $A$. marina leaves. Based on this study $A$. marina leaves contain complete minerals as forages for ruminant feed.

\section{Authors' Contributions}

GY, NJ, SS, BS, and RWWS: Formulated experimental design and experimental work at laboratory. GY: Drafted the manuscript and did data analysis under the guidance of NJ, SS, and BS. All the authors read and approved the final version of the manuscript.

\section{Acknowledgments}

This study was supported by Research Institution and Community Service Andalas University, Indonesia (Grant no.: T/13/UN.16.17/PT.01.03/Pangan-PDUKRP1GB/2020). This research would not have been possible without the technical field assistance of mangrove forest management staff in the coastal areas of West Sumatra and the Biotechnology Laboratory of the Faculty of Animal Husbandry, Andalas University.

\section{Competing Interests}

The authors declare that they have no competing interests.

\section{Publisher's Note}

Veterinary World remains neutral with regard to jurisdictional claims in published map and institutional affiliation.

\section{References}

1. Getzner, M. and Islam, M.S. (2020) Ecosystem services of mangrove forests: Results of a meta-analysis of economic values. Int. J. Environ. Res. Public Health, 17(16): 5830. 
2. Gilani, H., Naz, H., Arshad, M., Nazim, K., Akram, U., Abrar, A. and Asif, M. (2020) Evaluating mangrove conservation and sustainability through spatiotemporal (1990-2020) mangrove cover change analysis in Pakistan. Estuarine Coastal Mar. Sci., 249: 107128.

3. Qasim, M., Abideen, Z., Adnan, M.Y., Ansari, R., Gul, B. and Khan, M. (2014) Traditional ethno-botanical uses of medicinal plants from coastal areas of Pakistan journal of coastal life medicine. J. Coastal Life Med., 2(1): 1177.

4. Schweinzer, V., Iwersen, M., Drillich, M., Wittek, T., Tichy, A., Mueller, A. and Krametter-Froetscher, R. (2017) Macromineral and trace element supply in sheep and goats in Austria. Vet. Med., 62: 62-73.

5. Suttle, N. (2010) Mineral Nutrition of Livestock. $4^{\text {th }}$ ed. CAB International, London. p1-547.

6. Heriyanto, N.M. and Suharti, S. (2019) Water quality, soil fertility and heavy metal content in Nusa Penida mangrove forest, Bali. J. Penelitian Hutan Alam Konservasi, 16(1): 25-33..

7. Gmach, M.R., Cherubin, M., Kaiser, K. and Cerri, C.E. (2020) Processes that influence dissolved organic matter in the soil: A review. Sci. Agric., 77(3): e20180164.

8. Gordon, A. (2005) Oceanography of the Indonesian seas and their throughflow. Oceanography, 18(4): 14-27.

9. Kumar, J., Kumar, V., Rajanna, K., Naik, K. and Pandey, A. (2014) Ecological benefits of mangrove. Life Sci. Lealf., 48(2): 85-88.

10. Hugues, C., Bruno, M, Matthieu, V., Cohan, J.P., Champolivier, L., Piraux, F., Laurent, F. and Justes, E. (2017) Quantifying in situ and modeling net nitrogen mineralization from soil organic matter in arable cropping systems. Soil Biol. Biochem., 111: 44-59.

11. Powlson, D.S., Whitmore, A.P. and Goulding, K. (2011) Soil carbon sequestration to mitigate climate change: A critical re-examination to identify the true and the false. Eur. $J$. Soil Sci., 62(1): 42-55.

12. Ghosh, S., Chattoraj, S. and Nandi, A. (2015) Proximate composition of some mangrove leaves used as alternative fodders in Indian Sunderban region. Int. J. Livest. Res., 3(1): 1.

13. Irawati, N. (2011) Hubungan Produktivitas Primer Fitoplankton dengan Ketersediaan Unsur Hara Pada Berbagai Tingkat Kecerahan di Perairan Teluk Kendari, Sulawesi Tenggara. Tesis Sekolah Pasca Sarjana, Program Studi Pengelolaan Sumberdaya Perairan. Institut Pertanian Bogor.

14. Singh, J., Hundal, J., Sharma, A., Chahal, U., Aps, S. and Singh, P. (2018) Phosphorus nutrition in dairy animals: A review. Int. J. Curr. Microbiol. Appl. Sci., 7(4): 3518-3530.

15. Zhang, Z., Bi, M., Yang, J., Yao, H., Liu, Z. and Xu, S. (2016) Effect of phosphorus deficiency on erythrocytic morphology and function of cows. J. Vet. Sci., 18(3): 333-340.

16. Martens, H., Leonhard-Marek, S., Röntgen, M. and Stumpff, F. (2018) Magnesium homeostasis in cattle: Absorption and excretion. Nutr. Res. Rev., 31(1): 114-130.

17. Fairweather-Tait, S. and Cashman, K. (2015) Minerals and trace elements. World Rev. Nutr. Diet., 111: 45-52.

18. Costa e Silva, L.F., Filho, S.C.V., Engle, T.E., Rotta, P.P., Marcondes, M.I., Silva, F.A.S., Martins, E.C. and Tokunaga, A.T. (2015) Macrominerals and trace element requirements for beef cattle. PLoS One, 10(12): e0144464.

19. Wu, T., Liu, W., Wang, D., Zou, Y., Lin, R., Yang, Q., Gbokie, T., Bughio, M.A., Li, Q. and Wang, J. (2020) Organic management improves soil phosphorus availability and microbial properties in a tea plantation after land conversion from longan (Dimocarpus longan). J. Appl. Soil Ecol., 154: 103642.

20. Sattler, N. and Fecteau, G. (2014) Hypokalemia syndrome in cattle. Vet. Clin. North Am. Food Anim. Pract., 30(2): 351-357.

21. Ahuja, A. and Parmar, D. (2017) Role of minerals in reproductive health of dairy cattle: A review. Int. J. Livest. Res., 7(10): 16-26.

22. Maxwell, G. and Lai, H.Y. (2012) Avicennia marina foliage as a salt enrichment nutrient for New Zealand dairy cattle. ISME/GLOMIS Electron. J., 10(8): 22-24.

23. Sathe, S.S., Lavate, R.A. and Sajjan, M.B. (2015) The role of organic constituents of Avicennia in animal nutrition. Biosci. Discov., 6(2): 145-151.

24. Numbere, A. and Camilo, G. (2016) Mangrove leaf litter decomposition under mangrove forest stands with different levels of pollution in the Niger River Delta, Nigeria. Afr. $J$. Ecol., 55(2): 162-167.

25. White, H., Davis, N., Van Emon, M., Wyffels, S. and DelCurto, T. (2019) Impacts of increasing levels of salt on intake, digestion, and rumen fermentation with beef cattle consuming low-quality forages. Transl. Anim. Sci., 3(Suppl 1): 1818-1821.

26. Cope, C.M., Mackenzie, A., Wilde, D. and Sinclair, L. (2009) Effects of level and form of dietary zinc on dairy cow performance and health. J. Dairy Sci., 92(5): 2128-2135.

27. Cerone, S.I., Sansinanea, A.S., Streitenberger, S.A., Garcia, M.C. and Auza, N.J. (2000) Cytochrome c oxidase, $\mathrm{Cu}, \mathrm{Zn}$-superoxide dismutase, and ceruloplasmin activities in copper-deficient bovines. Biol. Trace Elem. Res., 73(3): 269-278.

28. Zhou, L., Long, R., Pu, X., Qi, J. and Zhang, W. (2009) Studies of a naturally occurring sulfur induced copper deficiency in Przewalski's gazelles. Can. Vet. J., 50(12): 1269-1272.

29. Mousavi, S.R., Shahsavari, M. and Rezaei, M. (2011) A general overview on manganese (Mn) importance for crops production. Aust. J. Basic Appl. Sci., 5(9): 1799-1803.

30. Hansen, S.L., Spears, J.W., Lloyd, K.E. and Whisnant, C.S. (2006) Feeding a low manganese diet to heifers during gestation impairs fetal growth and development. J. Dairy Sci., 89(11): 4305-4311.

31. Salobir, J., Korošec, T. and Rezar, V. (2012) Animal nutrition for the health of animals, human and environment. Acta Agric. Slov., 100: 41-49.

32. McGrath, J., Duval, S., Tamassia, L., Kindermann, M., Stemmler, R., Gouvêa, V., Acedo, T., Immig, I., Williams, S. and Celi, P. (2017) Nutritional strategies in ruminants: A lifetime approach. Res. Vet. Sci., 116: 28-39.

33. Kennady, V., Verma, R. and Chaudhiry, V. (2018) Detrimental impacts of heavy metals on animal reproduction: A review. J. Entomol. Zool. Stud., 6(6): 27-30.

34. Seedo, K., Abido, M. and Abahussain, A. (2017) Assessing heavy metals accumulation in the leaves and sediments of urban mangroves (Avicennia marina (Forsk.) Vierh.) in Bahrain. Int. J. Ecol., 2017: 3978216.

35. Egea, A.V., Allegretti, L.I., Lama, S.A.P., Grilli, D., Fucili, M., Guevara, J.C. and Villalba, J.J. (2016) Diet mixing and condensed tannins help explain foraging preferences by Creole goats facing the physical and chemical diversity of native woody plants in the central Monte desert (Argentina). Anim. Feed Sci. Technol., 215: 47-57. 